\title{
Kenneth Crossley McWalter
}

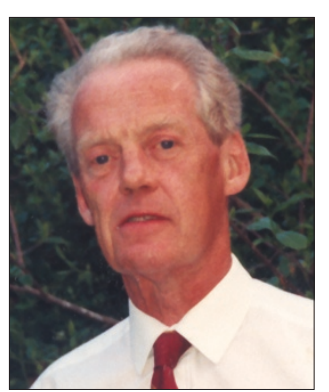

Ken McWalter, Vice-Chairman of the BDA Council from 1983-8, died on Friday 17 June 2005 in the Gloucester Royal Infirmary. With his passing the Western Counties Branch and the BDA as a whole lost one of its most distinguished members. Beneath his calm affable smile was a man to whom you could always turn for help. Ken was the perfect committee man. He read his papers assiduously, thought things through and was always prepared to give his point of view.

Born on 21 September 1931, Ken attended Cheadle Hulme School before studying dentistry at the Turner Dental School in Manchester, qualifying in December 1955. There followed a period to 1958 in the Army Dental Corps at Tidworth until he was demobilised at the rank of Captain. He entered general practice with a group of colleagues and established a highly successful and respected practice in Gloucester. Thereafter he turned his talents to working for his profession, being successively Secretary and Chairman of his local BDA Section, followed by holding the same offices for the Western Counties Branch. In 1974 he was elected from his branch to serve on the Representative Board of the Association and subsequently by

\section{Beneath his calm affable smile was a man to whom you could always turn for help.}

that governing body to serve on its Council. In 1983 he was elected by the Representative Board to become Vice Chairman of Council, a post he filled with distinction until 1988. In 1989 his loyalty and dedication were recognised by the award of the Association's Fellowship. Alas, also in 1989, after a brief illness he was diagnosed as having a neoplasm in the upper reaches of the maxilla. This was treated by radiotherapy, and although forced to give up his cigarettes he returned to work, retiring from his practice in 1993. Typical of the man this was not enough, so he enrolled at the University of Gloucestershire and in 1999 was awarded a BA (Hons) in English History. His patients and colleagues at Apsley House Surgery will all remember Ken with great fondness and respect.

Ken married Margaret Doreen in 1956 and our condolences go out to her and their three children Caroline, Elizabeth and Christopher.

B. Gillard

\section{William Hughes Williams}

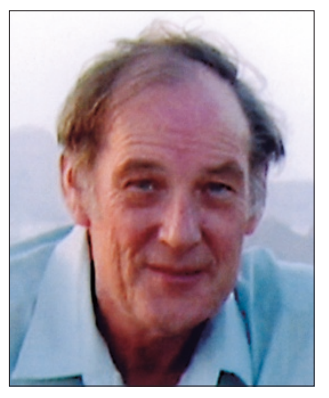

Bill Williams died suddenly but peacefully in his sleep on 8 July 2005. He was 59.

Born on 22 March 1946 in Cardiff, he lived in Blackwood until the age of seven when his family moved to live in Swansea. He attended Mumbles Primary School and Penlan Multilateral Secondary School before graduating from Cardiff Dental School in 1971.

Bill married Sandra while still a student. They moved to Birmingham where he worked in Birmingham General and Dudley Road Hospitals, attaining the first part of his FDS. He then became a Registrar and moved to Ipswich where he attained his full FDS.

On his return to Swansea, he had a brief spell in general dental practice before entering the then School Dental Service as a Dental Officer. He was subsequently appointed as Dental Service Manager of the CDS.

Bill was an exemplary clinician and exercised his full potential in treating patients with Special Needs, particularly adults.

\section{He always had time for all of his patients, and their best interests at heart.}

He was an inaugural member of the All Wales Special Interest Group Special Clinical Needs. He always had time for all of his patients, and their best interests at heart. He was truly a 'special needs' dentist.

Bill had many pastimes outside work - foremost his shooting. He was the ultimate 'Gadget Man', always researching for the best option in and out of work for the latest 'gismo'.

The dental profession as a whole and the CDS in Swansea in particular have lost a truly eccentric and charismatic member.

Bill was a devoted husband to Sandy, father to Nicholas and Richard and eldest son to 0. G. Williams, by whom he is survived. He will be missed greatly by all of his family, friends, patients and colleagues. 